Cite this: Dalton Trans., 2014, 43, 5401

Received 13th November 2013, Accepted 15th January 2014

DOI: 10.1039/c3dt53202j

www.rsc.org/dalton

\title{
A mass spectrometric and quantum chemical study of the vaporisation of lead monoxide in a flow of gaseous arsenic and antimony trioxides $\uparrow$
}

\author{
K. Kunkel, * E. Milke and M. Binnewies
}

\begin{abstract}
Mass spectrometric studies of the vapours over solid lead oxide in a flow of gaseous arsenic and antimony trioxides were conducted. The following ions of the ternary oxides were detected: $\mathrm{Pb}_{3} \mathrm{As}_{2} \mathrm{O}_{6}{ }^{+}, \mathrm{Pb}_{3} \mathrm{AsO}_{4}{ }^{+}$, $\mathrm{PbAs}_{2} \mathrm{O}_{4}{ }^{+}, \mathrm{PbAsO}_{2}{ }^{+}, \mathrm{PbSb}_{2} \mathrm{O}_{4}{ }^{+}$, and $\mathrm{PbSbO}_{2}{ }^{+}$. The origin of these species produced by the ionisation and/or fragmentation of ternary gaseous oxides is discussed. The $\mathrm{PbAs}_{2} \mathrm{O}_{4}$ species was undoubtedly identified by the determination of the appearance energy. Presumably, the $\mathrm{Pb}_{3} \mathrm{As}_{2} \mathrm{O}_{6}$ and $\mathrm{PbSb}_{2} \mathrm{O}_{4}$ species also existed in the gas phase. Thermodynamic data for the ternary oxides were obtained experimentally by means of a mass spectrometric Knudsen-cell method and were confirmed by quantum chemical calculations.
\end{abstract}

\section{Introduction}

Previously, we reported the following gaseous ternary oxides built from a transition metal and a main group metal or metalloid: $\mathrm{Sb}_{2} \mathrm{Mo}_{3} \mathrm{O}_{12}, \mathrm{Sb}_{2} \mathrm{M}_{2} \mathrm{O}_{9}, \mathrm{Sb}_{4} \mathrm{MO}_{9}, \mathrm{Sb}_{2} \mathrm{MO}_{6}$ (where $\mathrm{M}=$ Mo or W), $\mathrm{Mo}_{3} \mathrm{TeO}_{11}, \mathrm{Mo}_{2} \mathrm{TeO}_{8}, \mathrm{MoTe}_{2} \mathrm{O}_{7}$ and $\mathrm{MoTeO}_{15}{ }^{1,2}$ We continue our investigation of gaseous ternary oxides with a system consisting of a volatile metalloid oxide $\mathrm{X}_{2} \mathrm{O}_{3}$ (where $\mathrm{X}=$ As or $\mathrm{Sb}$ ) and the $\mathrm{PbO}$ metal oxide, which has a lower volatility. Several studies of the vaporisation of the pure oxides of $\mathrm{PbO},{ }^{3-5} \mathrm{As}_{2} \mathrm{O}_{3}{ }^{6,7}$ and $\mathrm{Sb}_{2} \mathrm{O}_{3}{ }^{8,9}$ using mass spectrometric methods have been reported by several authors. In the gas phase over solid lead monoxide at a temperature of approximately $1000 \mathrm{~K}, \mathrm{PbO}, \mathrm{Pb}_{2} \mathrm{O}_{2}$ and $\mathrm{Pb}_{4} \mathrm{O}_{4}$ were found to be the main compounds. Very low concentrations of $\mathrm{Pb}_{3} \mathrm{O}_{3}, \mathrm{~Pb}_{5} \mathrm{O}_{5}$ and $\mathrm{Pb}_{6} \mathrm{O}_{6}$ were also detected. ${ }^{3-5}$ Mass spectrometric studies of the vaporisation of $\mathrm{As}_{2} \mathrm{O}_{3}$ have shown that the gas phase of the As-O system is highly complex. ${ }^{6}$ Besides gaseous $\mathrm{As}_{4} \mathrm{O}_{6}$ and AsO species, which were previously known to exist in the gas phase, other stable species including $\mathrm{As}_{4} \mathrm{O}_{5}, \mathrm{As}_{4} \mathrm{O}_{4}, \mathrm{As}_{4} \mathrm{O}_{3}$, $\mathrm{As}_{3} \mathrm{O}_{4}, \mathrm{As}_{2} \mathrm{O}_{3}$ and $\mathrm{AsO}_{2}$ were detected in the gas phase. ${ }^{6}$ The studies of the $\mathrm{Sb}-\mathrm{O}$ system showed incongruent evaporation of $\mathrm{Sb}_{2} \mathrm{O}_{3}$ trioxide and revealed errors in previous studies on the congruent evaporation of $\mathrm{Sb}_{2} \mathrm{O}_{3} .{ }^{8,9}$ Analogous to the As-O system, the gas phase over antimony trioxide primarily consisted of $\mathrm{Sb}_{4} \mathrm{O}_{6}$ molecules. The formation and thermodynamic stability of antimony monoxide $\mathrm{SbO}$ have been previously

Institut für Anorganische Chemie, Callinstr. 9, 30167 Hannover, Germany.

E-mail: katja.kunkel@aca.uni-hannover.de; Fax: +49 511-762-2254

$\dagger$ Electronic supplementary information (ESI) available. See DOI: 10.1039/ c3dt53202j investigated by mass spectrometry. ${ }^{10}$ The authors observed the formation of SbO species by the oxidation of atomic $\mathrm{Sb}$ at temperatures of approximately $1880 \mathrm{~K}$.

There are several gaseous ternary oxides such as $\mathrm{SnPO}_{2}$, $\mathrm{SnPO}_{3}{ }^{11}$ and $\mathrm{GePO}_{3},{ }^{12}$ which are related to the lead-arsenic and lead-antimony oxides, which have been detected using mass spectrometry. To the best of our knowledge, no other experimental and quantum chemical studies of gaseous ternary molecular oxides of groups 14 and 15 elements have been reported. Two relative solid compounds $\mathrm{PbAs}_{2} \mathrm{O}_{4}$ and $\mathrm{Pb}_{2} \mathrm{As}_{2} \mathrm{O}_{5}$ were reported and their structures were investigated elsewhere. ${ }^{13}$ In the present work, with the help of mass spectrometry and quantum chemical calculations, we discuss the formation and stability of ternary oxides over two gaseous mixtures, $\mathrm{PbO}-\mathrm{As}_{2} \mathrm{O}_{3}$ and $\mathrm{PbO}-\mathrm{Sb}_{2} \mathrm{O}_{3}$. The structures of the gaseous ternary oxides $\mathrm{PbAs}_{2} \mathrm{O}_{4}, \mathrm{~Pb}_{3} \mathrm{As}_{2} \mathrm{O}_{6}$ and $\mathrm{PbSb}_{2} \mathrm{O}_{4}$ are also reported and discussed.

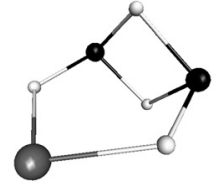

$\mathrm{PbAs}_{2} \mathrm{O}_{4}$

$\mathrm{PbSb}_{2} \mathrm{O}_{4}$

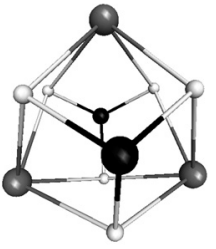

$\mathrm{Pb}_{3} \mathrm{As}_{2} \mathrm{O}_{6}$

\section{Results and discussion}

\subsection{Mass spectrometric study}

The $\mathrm{As}_{2} \mathrm{O}_{3}, \mathrm{Sb}_{2} \mathrm{O}_{3}$ and $\mathrm{PbO}$ oxides have very different volatilities. The melting points of the oxides are $585 \mathrm{~K}, 929 \mathrm{~K}$ and 
$1161 \mathrm{~K}$, respectively, and the equations describing the partial pressures as a function of temperature are as follows:

$$
\text { for } \begin{aligned}
\mathrm{As}_{2} \mathrm{O}_{3} \lg (p / \mathrm{atm})= & -(6067 \pm 125) / T+(9.905 \\
& \pm 0.319)(367-429 \mathrm{~K})
\end{aligned}
$$

$$
\text { for } \begin{aligned}
\mathrm{Sb}_{2} \mathrm{O}_{3} \lg (p / \mathrm{atm})= & -(10066 \pm 203) / T+(9.390 \\
& \pm 0.297)(627-723 \mathrm{~K})
\end{aligned}
$$

15

$$
\text { for } \mathrm{PbO} \lg (p / \text { bar })=-32032 / T+1915(850-1100 \mathrm{~K})
$$

$$
\text { or } \lg (p / \mathrm{Pa})=-13345 / T+11.9(900-1150 \mathrm{~K})
$$

16

Therefore, a double Knudsen cell was used in the mass spectrometric experiment. In the first experiment, solid $\mathrm{As}_{2} \mathrm{O}_{3}$ was continuously evaporated at $423 \mathrm{~K}$ and flowed through the solid $\mathrm{PbO}$ at $900 \mathrm{~K}$. Analogously, in the second experiment, $\mathrm{Sb}_{2} \mathrm{O}_{3}$ was evaporated at $673 \mathrm{~K}$ and flowed through the solid $\mathrm{PbO}$ at $1110 \mathrm{~K}$. The reaction products leaving the Knudsen cell were analysed by mass spectrometry.

The relative intensities of the ions in the mass spectra are presented in Table 1. Additionally, mass spectrometric measurements of the vaporisation of pure oxides were con-

\begin{tabular}{|c|c|c|c|c|c|}
\hline \multirow[b]{3}{*}{ Ion } & \multicolumn{5}{|c|}{ Relative intensity } \\
\hline & \multicolumn{2}{|c|}{$\mathrm{X}_{2} \mathrm{O}_{3}-\mathrm{PbO}$} & \multicolumn{2}{|l|}{$\mathrm{X}_{2} \mathrm{O}_{3}$} & \multirow{2}{*}{$\mathrm{PbO}$} \\
\hline & $\begin{array}{l}\mathrm{X}=\mathrm{As} \\
900 \mathrm{~K}\end{array}$ & $\begin{array}{l}X=S b \\
1100 \mathrm{~K}\end{array}$ & $\begin{array}{l}\mathrm{X}=\mathrm{As} \\
423 \mathrm{~K}\end{array}$ & $\begin{array}{l}\mathrm{X}=\mathrm{Sb} \\
673 \mathrm{~K}\end{array}$ & \\
\hline $\mathrm{Pb}_{4} \mathrm{O}_{4}^{+}\left(\mathrm{M}^{+}\right)$ & - & 6.0 & - & - & 100 \\
\hline $\mathrm{Pb}_{3} \mathrm{X}_{2} \mathrm{O}_{6}^{+}\left(\mathrm{M}^{+}\right)$ & 3.6 & - & - & - & - \\
\hline $\mathrm{Pb}_{3} \mathrm{XO}_{4}^{+}$ & 2.8 & - & - & - & - \\
\hline $\mathrm{Pb}_{3} \mathrm{O}_{3}^{+}\left(\mathrm{M}^{+}\right)$ & - & - & - & - & 10.5 \\
\hline $\mathrm{Pb}_{3} \mathrm{O}_{2}^{+}$ & - & - & - & - & 6.0 \\
\hline $\mathrm{Pb}_{2} \mathrm{O}_{2}^{+}$ & - & 2.9 & - & - & 59.7 \\
\hline $\mathrm{Pb}_{2} \mathrm{O}^{+}$ & - & - & - & - & 15.1 \\
\hline $\mathrm{PbX}_{2} \mathrm{O}_{4}^{+}\left(\mathrm{M}^{+}\right)$ & 37.5 & 7.9 & - & - & - \\
\hline $\mathrm{PbXO}_{2}{ }^{+}$ & 37.3 & 1.6 & - & - & - \\
\hline $\mathrm{X}_{4} \mathrm{O}_{6}^{+}\left(\mathrm{M}^{+}\right)$ & 100 & 100 & 100 & 100 & - \\
\hline $\mathrm{X}_{4} \mathrm{O}_{5}^{+}$ & 0.8 & - & 0.7 & 0.6 & - \\
\hline $\mathrm{X}_{4}^{+}$ & 22.7 & - & 0.8 & - & - \\
\hline $\mathrm{X}_{3} \mathrm{O}_{4}^{+}$ & 74.8 & 20.3 & 66.2 & 24.2 & - \\
\hline $\mathrm{X}_{3}^{+}$ & 1.8 & - & 1.6 & - & - \\
\hline $\mathrm{PbO}^{+}\left(\mathrm{M}^{+}\right)$ & - & 2.7 & - & - & 44.2 \\
\hline $\mathrm{Pb}^{+}$ & 18.7 & 11.6 & - & - & 45.1 \\
\hline $\mathrm{X}_{2} \mathrm{O}_{3}^{+}$ & 1.6 & - & 0.7 & 0.3 & - \\
\hline $\mathrm{X}_{2} \mathrm{O}_{2}^{+}$ & 5.7 & - & 0.7 & 2.7 & - \\
\hline $\mathrm{X}_{2}^{+{ }^{2}}$ & 14.0 & - & 4.4 & - & - \\
\hline $\mathrm{XO}^{+}$ & 37.5 & 0.7 & 14.1 & 5.1 & - \\
\hline $\mathrm{X}^{+}$ & 3.9 & 0.1 & 0.5 & 0.1 & - \\
\hline
\end{tabular}
ducted for comparison, and those results are also presented in Table 1. The highest relative intensities were observed for the $\mathrm{X}_{4} \mathrm{O}_{6}{ }^{+}$ions, and the second highest relative intensities

Table 1 Relative intensities of ionic species over $\mathrm{PbO}-\mathrm{X}_{2} \mathrm{O}_{3}$ systems and the pure oxides $\mathrm{X}_{2} \mathrm{O}_{3}(\mathrm{X}=\mathrm{As}$ or $\mathrm{Sb})$ and $\mathrm{PbO}$ at $70 \mathrm{eV}$ belonged to the $\mathrm{X}_{3} \mathrm{O}_{4}{ }^{+}$ions in the mass spectra of the ternary oxides as well as the pure arsenic and antimony trioxides. The $\mathrm{Pb}_{4} \mathrm{O}_{4}{ }^{+}, \mathrm{Pb}_{2} \mathrm{O}_{2}{ }^{+}$and $\mathrm{PbO}^{+}$ions were detected in the mass spectrometric experiment with antimony oxide $\left(\mathrm{PbO}-\mathrm{Sb}_{2} \mathrm{O}_{3}\right.$ system), in which $\mathrm{PbO}$ was heated to $1110 \mathrm{~K}$. In the experiment with arsenic oxide $\left(\mathrm{PbO}-\mathrm{As}_{2} \mathrm{O}_{3}\right.$ system), the partial pressure of $\mathrm{PbO}$ at $900 \mathrm{~K}$ was too low $\left(\sim 10^{-8}\right.$ bar $)$ for the detection of the $\mathrm{PbO}^{+}$signal in the mass spectra. Three parent ions of ternary oxides were detected: $\mathrm{Pb}_{3} \mathrm{As}_{2} \mathrm{O}_{6}{ }^{+}\left(\mathrm{M}^{+}\right), \mathrm{PbAs}_{2} \mathrm{O}_{4}{ }^{+}\left(\mathrm{M}^{+}\right)$and $\mathrm{PbSb}_{2} \mathrm{O}_{4}{ }^{+}\left(\mathrm{M}^{+}\right)$(where $\mathrm{M}^{+}$is the parent ion), which indicated the existence of gaseous $\mathrm{Pb}_{3} \mathrm{As}_{2} \mathrm{O}_{6}, \mathrm{PbAs}_{2} \mathrm{O}_{4}$ and $\mathrm{PbSb}_{2} \mathrm{O}_{4}$. The $\mathrm{Pb}_{2} \mathrm{As}_{2} \mathrm{O}_{5}{ }^{+}$ion was not detected. The appearance energy was obtained only for the $\mathrm{PbAs}_{2} \mathrm{O}_{4}{ }^{+}$ion because the intensities of the $\mathrm{Pb}_{3} \mathrm{As}_{2} \mathrm{O}_{6}{ }^{+}$and $\mathrm{PbSb}_{2} \mathrm{O}_{4}{ }^{+}$ions were too small. Extrapolation of the linear portion of the ionisation efficiency curves to an intensity of zero gave the following value for the appearance energy: $\mathrm{AE}\left(\mathrm{PbAs}_{2} \mathrm{O}_{4}{ }^{+}\right)=9.7 \pm 0.5 \mathrm{eV}$.

The following species, which can have two formation sources, were also observed: $\mathrm{Pb}_{3} \mathrm{AsO}_{4}{ }^{+}, \mathrm{PbAsO}_{2}{ }^{+}$and $\mathrm{PbSbO}_{2}{ }^{+}$. The first way in which these ions could have been formed was by the splitting of $\left[\mathrm{AsO}_{2}\right]$ from the $\mathrm{Pb}_{3} \mathrm{As}_{2} \mathrm{O}_{6}{ }^{+}$and $\mathrm{PbAs}_{2} \mathrm{O}_{4}{ }^{+}$ parent ions and the splitting of $\left[\mathrm{SbO}_{2}\right]$ from $\mathrm{PbSb}_{2} \mathrm{O}_{4}{ }^{+}$, i.e., by the fragmentation process

$$
\begin{aligned}
\mathrm{Pb}_{n} \mathrm{X}_{2} \mathrm{O}_{n+3}{ }^{+} \rightarrow & \mathrm{Pb}_{n} \mathrm{XO}_{n+1}^{+}+\left[\mathrm{XO}_{2}\right](\text { where } \mathrm{X}=\text { As or } \mathrm{Sb}, \\
& n=1 \text { or } 3)
\end{aligned}
$$

Under the designation $\left[\mathrm{XO}_{2}\right]$, neutral species were united to give a total of one $\mathrm{X}$ atom and two $\mathrm{O}$ atoms: $\mathrm{XO}_{2}, \mathrm{XO}+\mathrm{O}$, $\mathrm{X}+\mathrm{O}_{2}$ and $\mathrm{X}+2 \mathrm{O}$.

The second way in which the $\mathrm{Pb}_{3} \mathrm{AsO}_{4}{ }^{+}, \mathrm{PbAsO}_{2}{ }^{+}$and $\mathrm{PbSbO}_{2}{ }^{+}$ions could have been formed was as products of the ionisation of molecules with $\mathrm{X}^{2+}$. As mentioned above, gaseous AsO species, where the oxidation state of As is $2+$, are thermodynamically stable. Brittain et $a .^{6}$ have shown that $\mathrm{AsO}^{+}$ formed primarily by the ionisation of $\mathrm{AsO}(\mathrm{g})$ in unsaturated vapour over $\mathrm{As}_{2} \mathrm{O}_{3}(\mathrm{~s})$ at $1160 \mathrm{~K}$. In our experiment, the relative intensities of $\mathrm{AsO}^{+}$and $\mathrm{PbAsO}_{2}{ }^{+}$in the mass spectra of the $\mathrm{As}_{2} \mathrm{O}_{3}-\mathrm{PbO}$ gaseous mixture were quite high. The appearance energies for these two ions were determined to be $\mathrm{AE}\left(\mathrm{PbAsO}_{2}{ }^{+}\right)=$ $10.0 \pm 0.5 \mathrm{eV}$ and $\mathrm{AE}\left(\mathrm{AsO}^{+}\right)=15.7 \pm 0.5 \mathrm{eV}$. The quantum chemical calculated ionisation energies for the individual molecules are $\mathrm{IE}\left(\mathrm{PbAsO}_{2}\right)=6.74 \mathrm{eV}$ and $\mathrm{IE}(\mathrm{AsO})=8.48 \mathrm{eV}$, and the experimental value of Brittain et al. ${ }^{6}$ was $\mathrm{AE}\left(\mathrm{AsO}^{+}\right)=9.0 \pm$ $0.3 \mathrm{eV}$. Thus, under the conditions of our experiment, $\mathrm{AsO}^{+}$ and $\mathrm{PbAsO}_{2}{ }^{+}$ions were the fragmented species but were not the parent ions as was originally believed. The intensities of the $\mathrm{Pb}_{3} \mathrm{AsO}_{4}{ }^{+}$and $\mathrm{PbSbO}_{2}{ }^{+}$ions were too small to determine their appearance energies, but presumably, these ions were also fragments.

The dependence of the recorded ion currents on the partial pressure of the particular ion is described by the following equation:

$$
p_{i}=c \frac{\sum I_{i} T}{\sigma_{i} S_{i}}
$$


Table 2 Molecules and their ions in the gas phase of the $\mathrm{PbO}-\mathrm{As}_{2} \mathrm{O}_{3}$ system

\begin{tabular}{lll}
\hline Molecule & Attributed ions & $\begin{array}{l}\text { Partial pressure, } p \text { (bar) } \\
(900 \mathrm{~K})\end{array}$ \\
\hline $\mathrm{As}_{4} \mathrm{O}_{6}$ & $\mathrm{As}_{4} \mathrm{O}_{6}^{+}, \mathrm{As}_{4} \mathrm{O}_{5}^{+}, \mathrm{As}_{4}^{+}, \mathrm{As}_{3} \mathrm{O}_{4}^{+}, \mathrm{As}_{3}{ }^{+}$ & $3.1 \times 10^{-5}$ \\
$\mathrm{PbAs}_{2} \mathrm{O}_{4}$ & $\mathrm{PbAs}_{2} \mathrm{O}_{4}^{+}, \mathrm{PbAsO}_{2}^{+}{ }^{+}$ & $2.5 \times 10^{-5}$ \\
$\mathrm{~Pb}_{3} \mathrm{As}_{2} \mathrm{O}_{6}$ & $\mathrm{~Pb}_{3} \mathrm{As}_{2} \mathrm{O}_{6}{ }^{+}, \mathrm{Pb}_{3} \mathrm{AsO}_{4}{ }^{+}$ & $2.1 \times 10^{-6}$
\end{tabular}

Table 3 Molecules and their ions in the gas phase of the $\mathrm{PbO}-\mathrm{Sb}_{2} \mathrm{O}_{3}$ system

\begin{tabular}{lll}
\hline Molecule & Attributed ions & $\begin{array}{l}\text { Partial pressure, } p \text { (bar) } \\
(1100 \mathrm{~K})\end{array}$ \\
\hline $\mathrm{PbO}$ & $\mathrm{PbO}^{+}$ & $1.0 \times 10^{-7}$ \\
$\mathrm{Sb}_{4} \mathrm{O}_{6}$ & $\mathrm{Sb}_{4} \mathrm{O}_{6}^{+}, \mathrm{Sb}_{3} \mathrm{O}_{4}^{+}, \mathrm{SbO}^{+}, \mathrm{Sb}^{+}$ & $2.8 \times 10^{-6}$ \\
$\mathrm{PbSb}_{2} \mathrm{O}_{4}$ & $\mathrm{Sb}_{2} \mathrm{PbO}_{4}^{+}, \mathrm{SbPbO}_{2}^{+}$ & $3.6 \times 10^{-7}$
\end{tabular}

where $p_{i}=$ the partial pressure of component $i, c=$ the proportionality factor, $\sum I_{i}=$ the intensity of all of the ions formed by the ionisation and fragmentation of a gaseous molecule of $i, T=$ the temperature, $\sigma_{i}=$ the ionisation cross section and $S_{i}=$ the electron multiplier efficiency. The approximated eqn (6) can be used in most cases (the procedure of simplification is described elsewhere ${ }^{17}$ ):

$$
p_{i}=c \sum I_{i} T
$$

The proportionality factors $c_{1}$ and $c_{2}$ were determined by a calibration experiment for both systems and were found to be $c_{1}=3.6 \times 10^{-10}$ and $c_{2}=3.4 \times 10^{-11} \mathrm{bar} \mathrm{K}^{-1}$.

The mass spectrometric measurements of pure oxides $\mathrm{As}_{2} \mathrm{O}_{3}$ and $\mathrm{Sb}_{2} \mathrm{O}_{3}$ were used for the calibration. The proportional factors $c_{1}$ and $c_{2}$ were determined within the error of a factor of 8 and 7 respectively.

Using the $c_{1}$ and $c_{2}$ values, the relative intensities $\sum I_{i}$, and applying eqn (6), the partial pressures of the gaseous molecules in the two equilibrium gaseous mixtures $\mathrm{PbO}-\mathrm{As}_{2} \mathrm{O}_{3}$ and $\mathrm{PbO}-\mathrm{Sb}_{2} \mathrm{O}_{3}$ can be calculated (Table 2). It was taken into account that arsenic and antimony oxides were constantly evaporating at lower temperatures ( $423 \mathrm{~K}$ and $673 \mathrm{~K}$, respectively) and when they passed by lead oxide at higher temperatures ( $900 \mathrm{~K}$ and $1110 \mathrm{~K}$, respectively). Tables 2 and 3 present the parent ions, their fragments, which contributed to the gaseous molecules, and the partial pressures of these molecules. We assumed equilibrium inside the Knudsen cell in the systems under consideration. The equilibrium in the Knudsen cell was confirmed by vaporisation of $\mathrm{As}_{2} \mathrm{O}_{3}$ oxide. ${ }^{14}$ The equilibrium in the gas phase was investigated in the Knudsen cell over $\mathrm{Sb}_{2} \mathrm{O}_{3}$ and $\mathrm{PbO}$ oxides too. ${ }^{3-5,8,9,15}$

Using the partial pressures, we determined the equilibrium constants of the formation of the arsenic-lead and antimonylead ternary oxides, which will be given later in this paper.

\subsection{Density functional theory computations}

The def2-TZVP/RI-BP86 method allows a good correlation between the calculated values and the experimental data for many oxides to be obtained. We successfully used the method employed previously for studying oxide systems containing molybdenum, tungsten, tellurium and antimony oxides. ${ }^{1,2}$ We also used the def2-TZVP/RI-BP86 method in the current study and showed the correlation between the experimental and calculated data for arsenic, antimony and lead oxides.

First, the oxides $\mathrm{PbO}, \mathrm{Pb}_{2} \mathrm{O}_{2}, \mathrm{~Pb}_{3} \mathrm{O}_{3}, \mathrm{~Pb}_{4} \mathrm{O}_{4}$, and $\mathrm{X}_{4} \mathrm{O}_{6}$ (where $\mathrm{X}=\mathrm{As}$ or $\mathrm{Sb}$ ) were quantum chemically investigated. Total energies, thermal energies, point groups of the molecules and geometrical structures of pure lead, arsenic and antimony oxides are given in Table 4.

Monomers and oligomers of lead oxide, arsenic oxide and antimony oxide have also been theoretically studied elsewhere. ${ }^{18-20}$ The calculated geometrical structures with their point groups, bond lengths and angles in that study agree well with our calculations. Table 5 presents a comparison of the experimental structural data from the literature and our calculated structural data for lead, arsenic and antimony oxides. The geometric parameters for gaseous $\mathrm{As}_{4} \mathrm{O}_{6}$ and $\mathrm{Sb}_{4} \mathrm{O}_{6}$ obtained by electron diffraction agree well with the calculated values. The experimental data are also in good agreement.

The experimental and calculated vibration spectra of gaseous $\mathrm{As}_{4} \mathrm{O}_{6}, \mathrm{Sb}_{4} \mathrm{O}_{6}, \mathrm{~Pb}_{2} \mathrm{O}_{2}$ and $\mathrm{Pb}_{4} \mathrm{O}_{4}$ are presented in Table 6. The experimental frequencies and our calculated frequencies for $\mathrm{As}_{4} \mathrm{O}_{6}, \mathrm{Sb}_{4} \mathrm{O}_{6}, \mathrm{~Pb}_{4} \mathrm{O}_{4}, \mathrm{~Pb}_{2} \mathrm{O}_{2}$ and $\mathrm{PbO}$ are in

Table 4 Symmetries, total energies and thermal energies of the molecules (def2-TZVP/RI-BP86, scaling factor $=1.053$ )

\begin{tabular}{|c|c|c|c|c|}
\hline Molecule & $\begin{array}{l}\text { Point } \\
\text { group }\end{array}$ & Structure & $E_{\text {tot }}$ (a.u.) & $\begin{array}{l}E_{298}^{\text {therm }} \\
\left(\mathrm{kJ} \mathrm{mol}^{-1}\right)\end{array}$ \\
\hline $\mathrm{PbO}$ & $C_{\mathrm{cov}}$ & & -267.940878 & 10.99 \\
\hline $\mathrm{Pb}_{2} \mathrm{O}_{2}$ & $D_{2 \mathrm{~h}}$ & & -536.690429 & 26.83 \\
\hline $\mathrm{Pb}_{3} \mathrm{O}_{3}$ & $D_{3 \mathrm{~h}}$ & & -805.068223 & 44.09 \\
\hline $\mathrm{Pb}_{4} \mathrm{O}_{4}$ & $T_{\mathrm{d}}$ & & -1073.497158 & 60.50 \\
\hline $\begin{array}{l}\mathrm{As}_{4} \mathrm{O}_{6} \\
\mathrm{Sb}_{4} \mathrm{O}_{6}\end{array}$ & $\begin{array}{l}T_{\mathrm{d}} \\
T_{\mathrm{d}}\end{array}$ & & $\begin{array}{l}-9396.461653 \\
-1413.450842\end{array}$ & $\begin{array}{l}89.58 \\
85.86\end{array}$ \\
\hline AsO & $C_{\mathrm{ov}}$ & & -2311.386123 & 12.42 \\
\hline
\end{tabular}


Table 5 Experimental and calculated geometric parameters of gaseous molecules

\begin{tabular}{lllll}
\hline & & $r(\mathrm{M}-\mathrm{O}) \AA$ & $<(\mathrm{O}-\mathrm{M}-\mathrm{O})$ & $<(\mathrm{M}-\mathrm{O}-\mathrm{M})$ \\
\hline $\mathrm{Pb}_{4} \mathrm{O}_{4}$ & Exp. $^{21}$ & - & $86^{\circ}$ & $94^{\circ}$ \\
& Calc. $^{\circ}$ & 2.265 & $81.7^{\circ}$ & $97.8^{\circ}$ \\
$\mathrm{Pb}_{2} \mathrm{O}_{2}$ & Exp. $^{21}$ & - & $80^{\circ}$ & \\
& Calc. $^{2}$ & 2.138 & $83.3^{\circ}$ & \\
$\mathrm{As}_{4} \mathrm{O}_{6}$ & Exp. $^{22}$ & $1.80 \pm 0.02$ & $100 \pm 1.5^{\circ}$ & $126 \pm 3^{\circ}$ \\
& Calc. & 1.817 & $100.2^{\circ}$ & $125.8^{\circ}$ \\
$\mathrm{Sb}_{4} \mathrm{O}_{6}$ & Exp. $^{23}$ & $2.00 \pm 0.02$ & $98^{\circ}$ & $129.0 \pm 2.5$ \\
& Calc. & 1.986 & $98.6^{\circ}$ & $128.3^{\circ}$
\end{tabular}

Table 6 Observed and calculated vibrational frequencies for gaseous $\mathrm{As}_{4} \mathrm{O}_{6}, \mathrm{Sb}_{4} \mathrm{O}_{6}, \mathrm{~Pb}_{4} \mathrm{O}_{4}, \mathrm{~Pb}_{2} \mathrm{O}_{2}$ and $\mathrm{PbO}$ (scaling factor $=1$ )

\begin{tabular}{llllll}
\hline & \multicolumn{5}{c}{ Vibrational frequencies $\left(\mathrm{cm}^{-1}\right)$} \\
\hline $\mathrm{As}_{4} \mathrm{O}_{6}$ & Exp. $^{24}$ & 255.0 & 372.9 & 495.6 & 833.2 \\
& Calc. $^{24}$ & 239.3 & 350.3 & 470.0 & 779.1 \\
$\mathrm{Sb}_{4} \mathrm{O}_{6}$ & Exp. $^{25}$ & 172.2 & 292.4 & 415.6 & 785.0 \\
& Calc. & 165.2 & 270.7 & 401.5 & 741.4 \\
$\mathrm{~Pb}_{4} \mathrm{O}_{4}$ & Exp. $^{21}$ & - & 372 & 464 & \\
& Calc. & 113.3 & 353.3 & 451.8 & \\
$\mathrm{~Pb}_{2} \mathrm{O}_{2}$ & Exp. & - & 463 & 558 & \\
& Calc. & 86.6 & 455.2 & 542.7 & \\
$\mathrm{PbO}$ & Exp. & & \\
& Calc. & 714 & & & \\
& & 724.0 & & &
\end{tabular}

Table 7 Symmetries, total energies and thermal energies of the molecules (def2-TZVP/RI-BP86, scaling factor $=1.053$ )

\begin{tabular}{llll}
\hline Molecule & & $E_{\text {tot }}($ a.u. $)$ & $E_{298}^{\text {therm }}\left(\mathrm{kJ} \mathrm{mol}^{-1}\right)$ \\
\hline $\mathrm{PbAs}_{2} \mathrm{O}_{4}$ & $C_{\mathrm{s}}$ & -4966.580578 & 58.57 \\
$\mathrm{PbAsO}_{2}$ & $C_{1}$ & -2579.790596 & 28.36 \\
$\mathrm{~Pb}_{3} \mathrm{As}_{2} \mathrm{O}_{6}(\mathrm{I})$ & $D_{3 \mathrm{~h}}$ & -5503.395177 & 92.3 \\
$\mathrm{~Pb}_{3} \mathrm{As}_{2} \mathrm{O}_{6}$ (II) & $C_{3 \mathrm{v}}$ & -5503.369471 & 90.72 \\
$\mathrm{~Pb}_{3} \mathrm{As}_{2} \mathrm{O}_{6}$ (III) & $C_{\mathrm{S}}$ & -5503.364595 & 91.88 \\
$\mathrm{PbSb}_{2} \mathrm{O}_{4}$ & $C_{\mathrm{s}}$ & -975.065646 & 56.49
\end{tabular}

good agreement but almost all of the experimental frequencies (except $\mathrm{PbO}$ ) insignificantly (5-6\%) exceed the calculated values. Therefore vibrational wave numbers were calibrated using scaling factor $=1.053$.

Total energies, thermal energies and point groups for the ternary oxides $\mathrm{PbAs}_{2} \mathrm{O}_{4}, \mathrm{~Pb}_{3} \mathrm{As}_{2} \mathrm{O}_{6}, \mathrm{PbSb}_{2} \mathrm{O}_{4}$ and the hypothetical molecule $\mathrm{PbAsO}_{2}$ are presented in Table 7, and the structures are shown in Fig. 1. For $\mathrm{Pb}_{3} \mathrm{As}_{2} \mathrm{O}_{6}$, several structural isomers were found, and the optimised geometries and total energies of the isomers were also calculated and are presented in Table $7\left(E_{\text {tot }}(\mathrm{I})<E_{\text {tot }}(\mathrm{II})<E_{\text {tot }}(\mathrm{III})\right)$ and in Fig. 1.

Transitions between the isomers of $\mathrm{Pb}_{3} \mathrm{As}_{2} \mathrm{O}_{6}$ at the experimental temperature of $900 \mathrm{~K}$ can be characterised by Gibbs free energy: $\Delta_{i} G_{900}(\mathrm{II} \rightarrow \mathrm{I})=-51.9 \mathrm{~kJ} \mathrm{~mol}^{-1}$ and $\Delta_{i} G_{900}(\mathrm{III} \rightarrow \mathrm{I})=-66.1 \mathrm{~kJ} \mathrm{~mol}^{-1}$. According to the values of $\Delta_{i} G_{900}$, the ratio of the partial pressures of the isomers can be calculated at a temperature of $900 \mathrm{~K}: p\left(\mathrm{~Pb}_{3} \mathrm{As}_{2} \mathrm{O}_{6}(\mathrm{I})\right)$ : $p\left(\mathrm{~Pb}_{3} \mathrm{As}_{2} \mathrm{O}_{6}(\mathrm{II})\right): p\left(\mathrm{~Pb}_{3} \mathrm{As}_{2} \mathrm{O}_{6}(\mathrm{III})\right)=6843: 7: 1$. Because the partial pressures of $\mathrm{Pb}_{3} \mathrm{As}_{2} \mathrm{O}_{6}$ (II) and $\mathrm{Pb}_{3} \mathrm{As}_{2} \mathrm{O}_{6}$ (III) are insignificant in the gas phase, we will not consider them further.

The total energies of the cations $\mathrm{X}_{4} \mathrm{O}_{6}{ }^{+}, \mathrm{PbO}^{+}, \mathrm{PbX}_{2} \mathrm{O}_{4}{ }^{+}$, $\mathrm{PbAsO}_{2}{ }^{+}$and $\mathrm{Pb}_{3} \mathrm{As}_{2} \mathrm{O}_{6}{ }^{+}(\mathrm{X}=\mathrm{As}$ or $\mathrm{Sb})$ were computed in a doublet spin state in the geometry of a neutral molecule to determine the vertical ionisation energies (IE) of the corresponding molecules (Table 15 ESI $\dagger$ ). The first IE was determined as the difference between the total energy of the cation in a doublet state and the energy of the neutral molecule. Known experimental IE and $\mathrm{AE}$ values for the lead, arsenic and antimony oxides and $\mathrm{AE}$ values for $\mathrm{PbAs}_{2} \mathrm{O}_{4}{ }^{+}$and $\mathrm{PbAsO}_{2}{ }^{+}$ from the present study were compared with computed theoretical IE values (Table 8). The experimental $\mathrm{AE}$ values are in good agreement with theoretical IE values for all molecules except $\mathrm{PbAsO}_{2}$. This agreement confirms that the $\mathrm{PbAs}_{2} \mathrm{O}_{4}{ }^{+}$ion was formed by ionisation of ternary oxides rather than by fragmentation processes. If $\mathrm{PbAs}_{2} \mathrm{O}_{4}{ }^{+}$is a fragment of $\mathrm{Pb}_{3} \mathrm{As}_{2} \mathrm{O}_{6}{ }^{+}$, the $\mathrm{AE}\left(\mathrm{PbAs}_{2} \mathrm{O}_{4}^{+}\right)$is expected to be much higher. Our measured $\mathrm{AE}$ values for $\mathrm{PbAsO}_{2}{ }^{+}$and $\mathrm{AsO}^{+}$greatly exceeded the

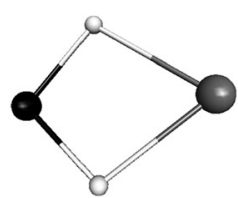

$\mathrm{PbAsO}_{2}$

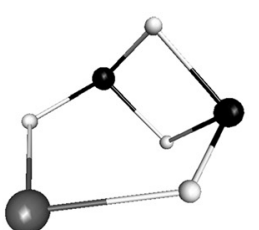

$\mathrm{PbAs}_{2} \mathrm{O}_{4}$

$\mathrm{PbSb}_{2} \mathrm{O}_{4}$

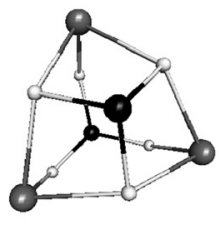

$\mathrm{Pb}_{3} \mathrm{As}_{2} \mathrm{O}_{6}$ (II)

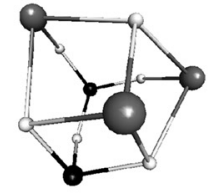

$\mathrm{Pb}_{3} \mathrm{As}_{2} \mathrm{O}_{6}(\mathrm{III})$

Fig. 1 Structures of the ternary oxides $\mathrm{PbAs}_{2} \mathrm{O}_{4}, \mathrm{PbAsO}_{2}, \mathrm{~Pb}_{3} \mathrm{As}_{2} \mathrm{O}_{6}, \mathrm{PbSb}_{2} \mathrm{O}_{4}$ and $\mathrm{Pb}_{3} \mathrm{AsO}_{4}$. 
Table 8 The calculated vertical first ionisation energies (IE) (def2TZVP/RI-BP86) and experimental appearance energies (AE)

\begin{tabular}{lcc}
\hline Molecule & $\begin{array}{l}\text { IE }(\mathrm{eV}) \\
\mathrm{QC}\end{array}$ & $\begin{array}{l}\text { AE, IE }(\mathrm{eV}) \\
\text { Exp. }\end{array}$ \\
\hline $\mathrm{PbO}$ & 9.65 & $9.4 \pm 0.3(\mathrm{EI}, \mathrm{AE})^{26}$ \\
& & $9.0 \pm 0.5(\mathrm{EI}, \mathrm{AE})^{5}$ \\
$\mathrm{~Pb}_{2} \mathrm{O}_{2}$ & 8.41 & $8.8 \pm 0.5(\mathrm{EI}, \mathrm{AE})^{5}$ \\
$\mathrm{As}_{4} \mathrm{O}_{6}$ & 9.60 & $10.05 \pm 0.05(\mathrm{PE}, \mathrm{IE})^{27}$ \\
$\mathrm{Sb}_{4} \mathrm{O}_{6}$ & 8.92 & $9.31 \pm 0.05(\mathrm{PE}, \mathrm{IE})^{27}$ \\
$\mathrm{AsO}$ & 8.48 & $9.0 \pm 0.3(\mathrm{EI}, \mathrm{AE})^{6}$ \\
$\mathrm{PbAs}_{2} \mathrm{O}_{4}$ & 9.07 & $9.7 \pm 0.5(\mathrm{EI})^{a}$ \\
$\mathrm{PbAsO}_{2}$ & 6.74 & $10.0 \pm 0.5(\mathrm{EI})^{a}$ \\
$\mathrm{~Pb}_{3} \mathrm{As}_{2} \mathrm{O}_{6}(\mathrm{I})$ & 8.47 & - \\
$\mathrm{PbSb}_{2} \mathrm{O}_{4}$ & 8.49 & - \\
$a_{\mathrm{This}_{4}}$ & &
\end{tabular}

calculated values, which means that these ions were formed by fragmentation.

Thermodynamic values for all of the compounds were obtained using the FREEH module and a scaling factor of 1.053 with a temperature range from the standard temperature to the temperature of the mass spectrometric experiments of 298-1000 K. The entropy, $S_{T}^{0}$, can be approximated as a function of temperature:

$$
\begin{aligned}
& S_{T}^{0}=S_{298}^{0}+\int_{298}^{T} c_{p, T}^{0} \frac{\mathrm{d} T}{T} \\
& \text { where } c_{p, T}^{0}=a+b \times 10^{-3} \times T+c \times 10^{6} \times T^{-2}
\end{aligned}
$$

The $a, b$ and $c$ coefficients of the heat capacity function $c_{p, T}^{0}$ were calculated mathematically by fitting ten values of $S_{T}^{0}$ in the temperature range of 298-1100 K. Calculated entropies for gaseous $\mathrm{PbO}, \mathrm{As}_{4} \mathrm{O}_{6}$, and $\mathrm{Sb}_{4} \mathrm{O}_{6}$ were compared with the experimental literature values to demonstrate the adequacy of the calculation method chosen (Table 9) for the study of thermodynamics. The calculated and experimental values of $S_{298}^{0}$ and $S_{1000}^{0}$ are in good agreement. The experimental and calculated values of coefficient $b$ of the $c_{p, T}^{0}$ function differ from each other but yield correct entropy values. Therefore, the calculated coefficients $a, b$ and $c$ for the ternary oxides are acceptable and can be used in the calculations. The calculated entropy values and the values of coefficients $a, b$ and $c$ for the ternary oxides are presented in Table 10.

The thermodynamics of gaseous monomer and oligomer molecules of lead oxides have been studied elsewhere. ${ }^{3-5}$ The enthalpies of oligomerisation for the lead oxides from the literature and our calculated values are compared in Table 11.
The calculated standard enthalpies of dimerisation and tetramerisation are in very good agreement with the literature values. The literature values of the enthalpy of the trimerisation process differ from each other and had an error of $\pm 25 \mathrm{~kJ}$ $\mathrm{mol}^{-1}$; our standard enthalpy value falls between the experimentally obtained ones. Thus, our method gives satisfactory results for the calculations of the enthalpies of reactions and can be used to investigate the thermodynamic characteristics of the ternary oxides.

Table 12 presents the reactions for the formation of the ternary lead-arsenic and lead-antimony oxides as well as the calculated enthalpies, entropies and equilibrium constants at standard and experimental temperatures for these reactions.

The calculated standard enthalpies of formation $\Delta_{\mathrm{f}} H_{298}^{0}$ of the ternary oxides have been obtained with the help of the reaction enthalpies $\Delta_{\mathrm{r}} H_{298}^{0}$ of the processes from Table 12 and the experimental values of $\Delta_{\mathrm{f}} H_{298}^{0}(\mathrm{PbO})=70.3 \mathrm{~kJ} \mathrm{~mol}^{-1},{ }^{28}$ $\Delta_{\mathrm{f}} H_{298}^{0}\left(\mathrm{As}_{4} \mathrm{O}_{6}\right)=-1196.1 \mathrm{~kJ} \mathrm{~mol}{ }^{-1},{ }^{28}$ and $\Delta_{\mathrm{f}} H_{298}^{0}\left(\mathrm{Sb}_{4} \mathrm{O}_{6}\right)=$ $-1215.5 \mathrm{~kJ} \mathrm{~mol}^{-128}$ and are as follows:

$$
\begin{gathered}
\Delta_{\mathrm{f}} H_{298}^{0}\left(\mathrm{PbAs}_{2} \mathrm{O}_{4}, \mathrm{QC}\right)=-668.5 \mathrm{~kJ} \mathrm{~mol}^{-1}, \\
\Delta_{\mathrm{f}} H_{298}^{0}\left(\mathrm{PbSb}_{2} \mathrm{O}_{4}, \mathrm{QC}\right)=-653.4 \mathrm{~kJ} \mathrm{~mol}^{-1}, \text { and } \\
\Delta_{\mathrm{f}} H_{298}^{0}\left(\mathrm{~Pb}_{3} \mathrm{As}_{2} \mathrm{O}_{6}, \mathrm{QC}\right)=-1107.8 \mathrm{~kJ} \mathrm{~mol}^{-1} .
\end{gathered}
$$

\subsection{Experimental determination of the standard enthalpies of formation of $\Delta_{\mathrm{f}} \mathrm{H}_{298}^{0}$}

The equilibrium constant $K_{p, T}$ is related to the reaction enthalpy, reaction entropy and temperature by the van't Hoff equation. The experimental reaction enthalpies $\Delta_{\mathrm{r}} H_{T}^{0}$ for processes $1^{\prime}, 2^{\prime}$ and 3 are calculated with eqn (8) and presented in Table 13 . The values of the reaction entropies $\Delta_{\mathrm{R}} S_{T}^{0}$ are calculated using quantum chemical values of entropy for ternary oxides and the experimental entropies $\mathrm{S}_{T}^{0}$ of $\mathrm{PbO}(\mathrm{s}), \mathrm{PbO}(\mathrm{g})$, $\mathrm{As}_{4} \mathrm{O}_{6}(\mathrm{~g})$, and $\mathrm{Sb}_{4} \mathrm{O}_{6}(\mathrm{~g})$ obtained from eqn (7) and the $c_{p, T}^{0}$ function. ${ }^{28}$

$$
\begin{gathered}
\Delta_{\mathrm{r}} H_{T}^{0}(\text { exp. })=-R T \ln K_{p, T}+T \Delta_{\mathrm{R}} \mathrm{S}_{T}^{0} \\
\Delta_{\mathrm{f}} H_{T^{\prime}}^{0}=\Delta_{\mathrm{f}} H_{T}^{0}+\int_{T}^{T^{\prime}} c_{p, T}^{0} d T
\end{gathered}
$$

The enthalpies of formation $\left(\Delta_{\mathrm{f}} H_{T}^{0}\right)$ of the ternary oxides (Table 14) were obtained using the determined enthalpies of reactions $\Delta_{\mathrm{r}} H_{T}^{0}$ (Table 13) and enthalpies of formation $\Delta_{\mathrm{f}} H_{T}^{0}$ of $\mathrm{PbO}(\mathrm{g}), \mathrm{PbO}(\mathrm{s}), \mathrm{As}_{4} \mathrm{O}_{6}(\mathrm{~g})$ and $\mathrm{Sb}_{4} \mathrm{O}_{6}(\mathrm{~g})$ oxides at experimental

Table 9 Experimental ${ }^{28}$ and calculated thermodynamic characteristics of lead, arsenic and antimony oxides (def2-TZVP/RI-BP86, scaling factor = 1.053)

\begin{tabular}{lllll}
\hline & & & \multicolumn{2}{c}{$c_{p, T}^{0}=a+b \times 10^{-3} \times T+c \times 10^{6} \times T^{-2}(\exp . / / \mathrm{QC})$} \\
\cline { 5 - 6 } Molecule & $\begin{array}{l}S_{298}^{0}\left(\mathrm{~J} \mathrm{~mol}^{-1} \mathrm{~K}^{-1}\right) \\
(\exp . / / \mathrm{QC})\end{array}$ & $\begin{array}{l}S_{1000}^{0}\left(\mathrm{~J} \mathrm{~mol}^{-1} \mathrm{~K}^{-1}\right) \\
(\exp . / / \mathrm{QC})\end{array}$ & $a$ & $b$ \\
\hline $\mathrm{PbO}(\mathrm{g})$ & $240.0 / / 240.1$ & $282.7 / / 282.2$ & $36.18 / / 35.14$ & $1.05 / / 2.00$ \\
$\mathrm{As}_{4} \mathrm{O}_{6}(\mathrm{~g})$ & $409.3 / / 409.0$ & $659.6 / / 659.0$ & $212.81 / / 218.22$ & $18.57 / / 12.86$ \\
$\mathrm{Sb}_{4} \mathrm{O}_{6}(\mathrm{~g})$ & $444.2 / / 454.0$ & $699.8 / / 709.1$ & $217.64 / / 220.99$ & $14.11 / / 10.39$
\end{tabular}


Table 10 Calculated thermodynamic characteristics of lead-arsenic and lead-antimony oxides (def2-TZVP/RI-BP86, scaling factor $=1.053$ )

\begin{tabular}{|c|c|c|c|c|}
\hline \multirow[b]{2}{*}{ Molecule } & \multirow[b]{2}{*}{$S_{298}^{0} / / S_{T}^{0}\left(\mathrm{~J} \mathrm{~mol}^{-1} \mathrm{~K}^{-1}\right)$} & \multicolumn{3}{|c|}{$\begin{array}{l}c_{p, T}^{0}=a+b \times 10^{-3} \times T+c \times \\
10^{6} \times T^{-2}\end{array}$} \\
\hline & & $a$ & $b$ & $c$ \\
\hline $\mathrm{PbAs}_{2} \mathrm{O}_{4}$ & $407.9 / / 563.4^{a}$ & 148.99 & 7.92 & -2.79 \\
\hline $\mathrm{PbSb}_{2} \mathrm{O}_{4}$ & $424.2 / / 614.7^{b}$ & 151.03 & 6.12 & -2.48 \\
\hline $\mathrm{Pb}_{3} \mathrm{As}_{2} \mathrm{O}_{6}(\mathrm{I})$ & $514.0 / / 773.9^{a}$ & 218.22 & 12.86 & -4.52 \\
\hline
\end{tabular}

Table 11 Comparison of the calculated and experimental values for the standard enthalpies of the equilibrium reactions of the lead oxides (def2-TZVP/RI-BP86, scaling factor $=1.053$ )

\begin{tabular}{lll}
\hline Reaction & $\begin{array}{l}\Delta_{\mathrm{r}} \mathrm{H}_{298}^{0}\left(\mathrm{~kJ} \mathrm{~mol}^{-1}\right) \\
\mathrm{QC}\end{array}$ & $\begin{array}{l}\Delta_{\mathrm{r}} H_{298}^{0}\left(\mathrm{~kJ} \mathrm{~mol}^{-1}\right) \\
\text { Exp. }^{(}\end{array}$ \\
\hline $2 \mathrm{PbO}(\mathrm{g}) \rightleftharpoons \mathrm{Pb}_{2} \mathrm{O}_{2}(\mathrm{~g})$ & -258.3 & $-250.6 \pm 6^{3}$ \\
& & $-265.4 \pm 17^{5}$ \\
$3 \mathrm{PbO}(\mathrm{g}) \rightleftharpoons \mathrm{Pb}_{3} \mathrm{O}_{3}(\mathrm{~g})$ & -470.4 & $-419.5 \pm 25^{3}$ \\
& & $-529.2 \pm 25^{5}$ \\
$4 \mathrm{PbO}(\mathrm{g}) \rightleftharpoons \mathrm{Pb}_{4} \mathrm{O}_{4}(\mathrm{~g})$ & -816.7 & $-835.0 \pm 15^{3}$ \\
& & $-845.7 \pm 42^{5}$ \\
${ }^{a}$ Mass spectrometric experiment. &
\end{tabular}

temperatures, which were obtained from eqn (9) and the experimental $c_{p, T}^{0}$ function ${ }^{28}\left(\Delta_{\mathrm{f}} H_{900}^{0}(\mathrm{PbO}(\mathrm{s}))=-187.2 \mathrm{~kJ} \mathrm{~mol}^{-1}\right.$, $\Delta_{\mathrm{f}} H_{900}^{0}\left(\mathrm{As}_{4} \mathrm{O}_{6}(\mathrm{~g})\right)=-1070.3 \mathrm{~kJ} \mathrm{~mol}^{-1}, \Delta_{\mathrm{f}} H_{900}^{0}(\mathrm{AsO}(\mathrm{g}))=75.6 \mathrm{~kJ}$ $\mathrm{mol}^{-1}, \quad \Delta_{\mathrm{f}} H_{1110}^{0}(\mathrm{PbO}(\mathrm{g}))=99.4$ and $\Delta_{\mathrm{f}} H_{1110}^{0}\left(\mathrm{Sb}_{4} \mathrm{O}_{6}(\mathrm{~g})\right)=$ $-1039.2 \mathrm{~kJ} \mathrm{~mol}^{-1}$ ). Then, the calculated enthalpies of formation $\Delta_{\mathrm{f}} H_{T}^{0}$ of the ternary oxides were converted into the standard enthalpies of formation $\Delta_{\mathrm{f}} H_{298}^{0}$ using eqn (9) and the calculated $a, b$ and $c$ coefficients of the $c_{p, T}^{0}$ function (Table 10). The deviations of the experimental values are discussed in the next section. The experimental enthalpies $\Delta_{\mathrm{f}} H_{T}^{0}$ and $\Delta_{\mathrm{f}} H_{298}^{0}$ and the quantum chemical values of $\Delta_{\mathrm{f}} H_{298}^{0}$ of the ternary oxides are presented in Table 14 for comparison.

\subsection{Error estimation by the determination of the experimental standard enthalpies of formation}

In the present section we estimate errors in the determination of the standard enthalpy of formation. The proportional factors $c_{1}$ and $c_{2}$ were determined within the errors of a factor of 8 and 7 respectively. The errors of proportional factors lead to the errors of equilibrium constant $K_{p, T}$ and give the
Table 13 Experimental equilibrium constant and enthalpies of reaction

\begin{tabular}{|c|c|c|c|}
\hline & Reaction & $\ln K_{p, T}$ & $\begin{array}{l}\Delta_{\mathrm{r}} H_{T}^{0} \\
\left(\mathrm{~kJ} \mathrm{~mol}{ }^{-1}\right)\end{array}$ \\
\hline $1^{\prime}$ & $\begin{array}{l}\mathrm{PbO}(\mathrm{s})+1 / 2 \mathrm{As}_{4} \mathrm{O}_{6}(\mathrm{~g}) \rightleftharpoons \\
\mathrm{PbAs}_{2} \mathrm{O}_{4}(\mathrm{~g})\end{array}$ & $-5.4 \pm 1.4^{a}$ & $149.1 \pm 19.5^{a}$ \\
\hline $2^{\prime}$ & $\begin{array}{l}3 \mathrm{PbO}(\mathrm{s})+1 / 2 \mathrm{As}_{4} \mathrm{O}_{6}(\mathrm{~g}) \rightleftharpoons \\
\mathrm{Pb}_{3} \mathrm{As}_{2} \mathrm{O}_{6}(\mathrm{~g})\end{array}$ & $-7.9 \pm 1.2^{a}$ & $132.3 \pm 18.0^{a}$ \\
\hline 3 & $\begin{array}{l}\mathrm{PbO}(\mathrm{g})+1 / 2 \mathrm{Sb}_{4} \mathrm{O}_{6}(\mathrm{~g}) \rightleftharpoons \\
\mathrm{PbSb}_{2} \mathrm{O}_{4}(\mathrm{~g})\end{array}$ & $7.7 \pm 1.4^{b}$ & $-112.8 \pm 18.5^{b}$ \\
\hline
\end{tabular}

deviation of $\ln K_{p, T} \pm 1.1$ for reactions $1^{\prime}, 2^{\prime}$ and \pm 1.0 for reaction 3. The error of the sum of ions $\sum I_{i}$ (eqn (6)) could reach $20 \%$. That contributes to the errors of $\ln K_{p, T}$ the values \pm 0.3 , \pm 0.1 and \pm 0.4 for reactions $1^{\prime}, 2^{\prime}$ and 3 respectively.

The error in determination of enthalpy of reaction $\Delta_{\mathrm{r}} H_{T}^{0}$ includes both the error of equilibrium constant and the error of entropy of reaction according to eqn (8). The error of entropy of reaction 3 is lower than errors of entropy of reactions $1^{\prime}$ and $2^{\prime}$, because the entropies of reactions $\Delta_{\mathrm{r}} S_{T}^{0}\left(1^{\prime}\right)$ and $\Delta_{\mathrm{r}} S_{T}^{0}\left(2^{\prime}\right)$ include both experimental and quantum chemical calculated entropies and $\Delta_{\mathrm{r}} S_{T}^{0}(3)$ is a quantum chemical value. We estimate the errors of $\Delta_{\mathrm{r}} S_{T}^{0}\left(1^{\prime}\right)$ and $\Delta_{\mathrm{r}} S_{T}^{0}\left(2^{\prime}\right)$ to be $\pm 10 \mathrm{~J}$ $\mathrm{mol}^{-1} \mathrm{~K}^{-1}$ and the error of $\Delta_{\mathrm{r}} S_{T}^{0}(3)$ to be $\pm 5 \mathrm{~J} \mathrm{~mol}^{-1} \mathrm{~K}^{-1}$.

Then the total errors of enthalpy of reactions $1^{\prime}, 2^{\prime}$ and 3 are equal to $\pm 19.5, \pm 18.0$ and $\pm 18.5 \mathrm{~kJ} \mathrm{~mol}^{-1}$ respectively. The errors of standard enthalpy of formation $\Delta_{\mathrm{f}} H_{298}^{0}$ have corresponding deviations and are given in Table 14. The differences between the calculated and experimental enthalpies of formation are not very large. The biggest difference of $\Delta_{\mathrm{f}} H_{298}^{0}(\exp )$ $-\Delta_{\mathrm{f}} H_{298}^{0}(\mathrm{QC})$ is for the $\mathrm{Pb}_{3} \mathrm{As}_{2} \mathrm{O}_{6}$ molecule and is equal to $17.5 \mathrm{~kJ} \mathrm{~mol}^{-1}$.

\section{Experimental}

\subsection{Samples}

Yellow lead monoxide (grade puriss. p.a), arsenic trioxide (grade puriss. p.a) and antimony trioxide (grade puriss. p.a) were used in the present study.

\subsection{Mass spectrometry}

Mass spectrometric measurements were carried out using a modified Finnigan type mass spectrometer. The vapours effusing from the Knudsen cell were ionised with $70 \mathrm{eV}$

Table 12 Calculated standard enthalpies, entropies of reaction and equilibrium constants for the equilibrium processes in which the lead-arsenic and lead-antimony oxides participate (def2-TZVP/RI-BP86, scaling factor $=1.053$ )

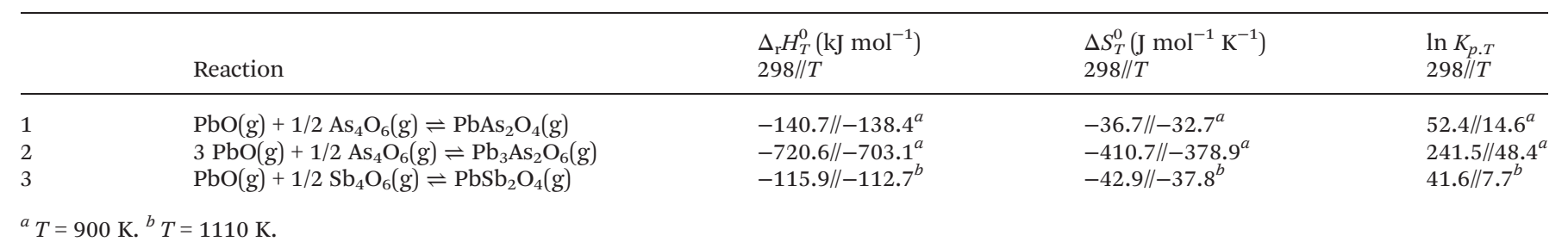


Table 14 Experimental enthalpies of formation for lead-arsenic and lead-antimony oxides

\begin{tabular}{lllrl}
\hline Compound & $\begin{array}{l}\Delta_{\mathrm{f}} H_{T}^{0}\left(\mathrm{~kJ} \mathrm{~mol}^{-1}\right) \\
\text { Exp. }\end{array}$ & $\begin{array}{l}\Delta_{\mathrm{f}} H_{298}^{0}\left(\mathrm{~kJ} \mathrm{~mol}^{-1}\right) \\
\text { Exp. }\end{array}$ & $\begin{array}{l}\Delta_{\mathrm{f}} H_{298}^{0}(\mathrm{QC}) \\
\mathrm{kJ} \mathrm{mol}^{-1}\end{array}$ & $\begin{array}{r}\Delta_{\mathrm{f}} H_{298}^{0}(\mathrm{exp} .)-\Delta_{\mathrm{f}} H_{298}^{0}(\mathrm{QC}) \\
\mathrm{kJ} \mathrm{mol}\end{array}$ \\
\hline $\mathrm{PbAs}_{2} \mathrm{O}_{4}$ & $-573.2 \pm 19.5^{a}$ & $-659.5 \pm 19.5$ & -668.5 & 9.0 \\
$\mathrm{~Pb}_{3} \mathrm{As}_{2} \mathrm{O}_{6}$ & $-964.4 \pm 18.0^{a}$ & $-1090.3 \pm 18.0$ & -1107.8 & -17.5 \\
$\mathrm{PbSb}_{2} \mathrm{O}_{4}$ & $-549.9 \pm 18.5^{b}$ & $-669.9 \pm 18.5$ & -653.4 & -16.5 \\
${ }^{a} T=900 \mathrm{~K} .{ }^{b} T=1110 \mathrm{~K}$. & & & &
\end{tabular}

electrons and accelerated to $3000 \mathrm{~V}$. Ion currents were detected by an electron multiplier at $1.6-2.0 \mathrm{kV}$. Two systems were experimentally investigated in the gas phase: $\mathrm{X}_{2} \mathrm{O}_{3}-\mathrm{PbO}$, where $\mathrm{X}=\mathrm{As}$ or $\mathrm{Sb}$. A quartz double Knudsen cell (described elsewhere $^{29}$ ) with an effusion orifice $1 \mathrm{~mm}$ in diameter was employed in the investigation of these systems. Temperature was measured with a Pt-Pt/Rh thermocouple. $\mathrm{X}_{2} \mathrm{O}_{3}$ oxides were continuously evaporated $\left(\mathrm{As}_{2} \mathrm{O}_{3}\right.$ at $423 \mathrm{~K}$ and $\mathrm{Sb}_{2} \mathrm{O}_{3}$ at $\left.673 \mathrm{~K}\right)$ and flowed through solid lead oxide, which was heated to $900 \mathrm{~K}$ and $1110 \mathrm{~K}$, respectively. The reaction products leaving the Knudsen cell were analysed by mass spectrometry. The same method with a double Knudsen cell was previously applied in the study of the $\mathrm{Sb}_{2} \mathrm{O}_{3}-\mathrm{WO}_{3}$ system. ${ }^{1}$ Appearance energies (AEs) of the ions of the ternary oxides were obtained by varying the electron energy to determine the onset of the ions.

\subsection{Quantum chemical calculations}

Quantum chemical calculations were performed using the TURBOMOLE program package. ${ }^{30}$ All of the structures of the molecules were fully optimised using density functional theory (DFT) with the BP86 functional and the def2-TZVP triple split valence basis set with a polarisation function and small core ECP functions. RI-treatment was also applied. All computational details have been described in our previous studies. ${ }^{1,2}$

\section{Conclusions}

The existence of three novel ternary lead-arsenic and leadantimony oxides $\left(\mathrm{PbAs}_{2} \mathrm{O}_{4}, \mathrm{~Pb}_{3} \mathrm{As}_{2} \mathrm{O}_{6}\right.$ and $\left.\mathrm{PbSb}_{2} \mathrm{O}_{4}\right)$ in the gas phase was proven by means of mass spectrometry. The gas phase of both systems primarily contained $\mathrm{X}_{4} \mathrm{O}_{6}$ and $\mathrm{PbX}_{2} \mathrm{O}_{4}$ oxides ( $\mathrm{X}=\mathrm{As}$ or $\mathrm{Sb}$ ). The $\mathrm{PbAs}_{2} \mathrm{O}_{4}$ and $\mathrm{PbSb}_{2} \mathrm{O}_{4}$ oxides are isostructural, have two-coordinate atoms of $\mathrm{Pb}$ and three-coordinated atoms of X. Similar structures have been observed for the $\mathrm{Sb}_{2} \mathrm{MoO}_{6}$ and $\mathrm{Sb}_{2} \mathrm{WO}_{6}$ oxides. ${ }^{1,2}$ The $\mathrm{Pb}_{3} \mathrm{As}_{2} \mathrm{O}_{6}$ oxide has a cage-like structure with high symmetry $D_{3 \mathrm{~h}}$ and contains four-coordinate atoms of $\mathrm{Pb}$ (Fig. 1). The $\mathrm{Pb}_{2} \mathrm{X}_{2} \mathrm{O}_{5}$ oxides were not detected. The oxidation state of $\mathrm{Pb}$ is $2+$ and that of $\mathrm{X}$ is $3+$ as in $\mathrm{PbO}$ and $\mathrm{X}_{4} \mathrm{O}_{6}$ oxides. The maximum number of metallic atoms found in these gaseous ternary compounds was five, similar to the results of our previous studies on antimonymolybdenum and antimony-tungsten ternary oxides. ${ }^{1}$
It is known that $\mathrm{SnPO}_{2}$, which is isoelectronic with $\mathrm{PbAsO}_{2}$, is a stable species. ${ }^{11} \mathrm{AsO}^{6}$ also existed in the gas phase. The $\mathrm{PbAsO}_{2}{ }^{+}$and $\mathrm{AsO}^{+}$ions have large intensities in our mass spectrum, which allowed us to suspect the presence of $\mathrm{PbAsO}_{2}$ in the gas phase. However, the determination of the appearance energy of $\mathrm{PbAsO}_{2}{ }^{+}$did not confirm our assumptions.

The $\mathrm{PbO}-\mathrm{As}_{2} \mathrm{O}_{3}$ system has different compounds in the solid state and the gas phase. As was mentioned above, two solid compounds $\mathrm{PbAs}_{2} \mathrm{O}_{4}$ and $\mathrm{Pb}_{2} \mathrm{As}_{2} \mathrm{O}_{5}$ were reported. ${ }^{13}$ Our study did not confirm the presence of $\mathrm{Pb}_{2} \mathrm{As}_{2} \mathrm{O}_{5}$ in the gas phase, but $\mathrm{Pb}_{3} \mathrm{As}_{2} \mathrm{O}_{6}$ which is not known in the solid state was detected in the gas phase.

The enthalpies of formation of the ternary oxides in the gas phase were determined using mass spectrometry and were compared with quantum chemical calculations. The experimental and calculated standard enthalpies of formation are in very good agreement.

The partial pressures of the ternary lead-arsenic species are about 3 to 4 order of magnitude higher than the partial pressures of pure lead monoxide at the same temperature. The fraction of lead-containing species is enhanced in the presence of $\mathrm{As}_{4} \mathrm{O}_{6}$ by a factor of 5000 .

\section{Acknowledgements}

We gratefully acknowledge the Steinbuch Computing Centre of the Karlsruhe Institute of Technology for the use of their computing facilities and Dr Ralf Köppe for his assistance.

\section{References}

1 E. Berezovskaya, E. Milke and M. Binnewies, Dalton Trans., 2012, 41(8), 2464.

2 E. Berezovskaya, E. Milke and M. Binnewies, Dalton Trans., 2012, 41(35), 10769.

3 A. Popovič, A. Lesar, M. Guček and L. Bencze, Rapid Commun. Mass Spectrom., 1997, 11, 459.

4 O. Knacke and A. von Richthofen, Z. Phys. Chem., 1994, 187, 257.

5 J. Drowart, R. Colin and G. Exsteen, J. Chem. Soc., Faraday Trans., 1965, 61, 1376.

6 R. D. Brittain, K. H. Lau and D. L. Hlidenbrand, J. Phys. Chem., 1982, 86, 5072. 
7 G. Chiavari, D. Fabbri and G. C. Galletti, Rapid Commun. Mass Spectrom., 1995, 9, 559.

8 N. A. Asryan, A. S. Alikhanyan and G. D. Nipan, Inorg. Mater., 2004, 40, 626.

9 N. A. Asryan, A. S. Alikhanyan and G. D. Nipan, Russ. J. Phys. Chem., 2003, 78, 5.

10 G. A. Semenov, Russ. J. Phys. Chem., 1985, 59, 1520.

11 S. I. Lopatin and G. A. Semenov, Russ. J. Gen. Chem., 1996, 66, 180 .

12 V. L. Stolyarova, S. I. Shornikov, G. G. Ivanov and M. M. Shultz, Rapid Commun. Mass Spectrom., 1990, 4, 510512.

13 S. Bahfenne, L. Rintoul, J. Langhof and R. L. Frost, J. Raman Spectrosc., 2011, 42, 2119.

14 R. G. Behrens and G. M. Rosenblatt, J. Chem. Thermodyn., 1972, 4, 175.

15 R. G. Behrens and G. M. Rosenblatt, J. Chem. Thermodyn., 1973, 5, 173.

16 S. I. Lopatin, I. Ya. Mittova, F. S. Gerasimov, S. M. Shugurov, V. F. Kostryukov and S. M. Skorokhodova, Russ. J. Inorg. Chem., 2006, 51, 1749.

17 M. Binnewies, K. Rinke and H. Schäfer, Z. Anorg. Allg. Chem., 1973, 395, 50.

18 H. Liu, S. Wang, G. Zhou, J. Wu and W. Duan, J. Chem. Phys., 2007, 126, 134705.

19 J. O. Jensen, S. J. Gilliam, A. Banerjee, D. Zeroka, S. J. Kirkby and C. N. Merrow, J. Mol. Struct. (THEOCHEM), 2003, 664-665, 145.
20 S. J. Gilliam, J. O. Jensen, A. Banerjee, D. Zeroka, S. J. Kirkby and C. N. Merrow, Spectrochim. Acta, Part A, 2004, 60, 425.

21 R. K. Khanna and Y. J. Park, Spectrochim. Acta, 1986, 42A, 603.

22 G. C. Hampson and A. J. Stosick, J. Am. Chem. Soc., 1938, 60, 1814.

23 P. A. Akishin and V. P. Spiridonov, J. Struct. Chem., 1961, 2, 502.

24 R. J. M. Konings, E. H. P. Cordfunke and A. S. Booij, J. Mol. Struct., 1992, 152, 29.

25 R. J. M. Konings, A. S. Booij and E. H. P. Cordfunke, Chem. Phys. Lett., 1993, 210, 380.

26 A. V. Makarov and S. G. Zbezhneva, Vysokochist. Veshchestva, 1993, 1, 124.

27 R. G. Egdell, M. H. Palmer and R. H. Findlay, Inorg. Chem., 1980, 19, 1314.

28 M. Binnewies and E. Milke, Thermochemical data of Elements and Compounds, 2nd edn, Wiley-VCH, 2002.

29 M. Binnewies, Z. Anorg. Allg. Chem., 1977, 435, 156.

30 R. Ahlrichs, M. Bär, H.-P. Baron, R. Bauernschmitt, S. Böcker, P. Deglmann, M. Ehrig, K. Eichkorn, S. Elliott, F. Furche, F. Haase, M. Häser, C. Hättig, H. Horn, C. Huber, U. Huniar, M. Kattannek, A. Köhn, C. Kölmel, M. Kollwitz, K. May, C. Ochsenfeld, H. Öhm, A. Schäfer, U. Schneider, M. Sierka, O. Treutler, B. Unterreiner, M. von Arnim, F. Weigend, P. Weis and H. Weiss, Turbomole (vers. 5.9.1), Universität Karlsruhe, 2007. 